\title{
LENGTH-WEIGHT RELATIONS OF JUVENILE AND ADULT FISHES (ACTINOPTERYGII) FROM SHALLOW WATERS IN THE LOWER GUANABARA BAY ESTUARY, BRAZIL
}

\author{
Marcus R. da COSTA ${ }^{1,3^{*}}$, Rafael de A. TUBINO ${ }^{1,2}$, and Cassiano MONTEIRO-NETO ${ }^{1,3}$ \\ ${ }^{1}$ Laboratório de Biologia do Nécton e Ecologia Pesqueira (ECOPESCA), Universidade Federal Fluminense, \\ Niterói, Brazil \\ ${ }^{2}$ Departamento de Biologia Animal, Universidade Federal Rural do Rio de Janeiro, Seropédica, Brazil \\ ${ }^{3}$ Programa de Pós-Graduação em Biologia Marinha e Ambientes Costeiros, Departamento de Biologia Marinha, \\ Instituto de Biologia, Niterói, Brazil
}

da Costa M.R., Tubino R.A., Monteiro-Neto C. 2018. Length-weight relations of juvenile and adult fishes (Actinopterygii) from shallow waters in the lower Guanabara Bay estuary, Brazil. Acta Ichthyol. Piscat. 48 (2): 199-204.

\begin{abstract}
Length-weight relations (LWR) are presented herewith for 15 fish species from shallow waters of three sandy beaches in the lower Guanabara Bay estuary, south-eastern Brazil. The following species were examined: Albula vulpes (Linnaeus, 1758); Harengula clupeola (Cuvier, 1829); Brevoortia aurea (Spix et Agassiz, 1829); Anchoa lyolepis (Evermann et Marsh, 1900); Umbrina coroides Cuvier, 1830; Menticirrhus littoralis (Holbrook, 1847); Menticirrhus americanus (Linnaeus, 1758); Trachinotus carolinus (Linnaeus, 1766); Trachinotus falcatus (Linnaeus, 1758); Diplodus argenteus (Valenciennes, 1830); Polydactylus virginicus (Linnaeus, 1758); Mugil curema Valenciennes, 1836; Haemulon aurolineatum Cuvier, 1830; Haemulon steindachneri (Jordan et Gilbert, 1882); Sphoeroides testudineus (Linnaeus, 1758). Specimens were sampled monthly over a four-year period between January 2012 and December 2015. This study presents the first length-weight relation of Diplodus argenteus for Brazil. The LWRs for all taxa included juveniles and sub-adults within size ranges commonly found in shallow waters of tropical sandy beaches. Only the adults $\left(\mathrm{TL}>L_{50}\right)$ of Harengula clupeola and Sphoeroides testudineus were recorded in the area. The length-weight parameter $b$ for all species ranged from 2.66 to 3.32, with regression coefficients $\left(r^{2}\right)$ between 0.97 and 0.99 .
\end{abstract}

Keywords: ichthyofauna, sandy beach, south-eastern Brazil, growth

\section{INTRODUCTION}

The length-weight relation (LWR) in fish biology is useful for predicting weight from length values, indicating a fish condition, and conducting a fish stock assessment (Lin and Tzeng 2010, Romdhani et al. 2013). The relation may also provide information for between region comparisons of species life histories and population dynamics (da Costa et al. 2014).

Since the last century, many ichthyologists have discussed the causes and meanings of growth in fish (e.g., Huxley 1924, 1993, Le Cren 1951, Beyer 1987). Growth rates may vary, among other factors, according to environmental conditions, food availability, and habitat type. Nevertheless, a common pattern on fish growth is the development through a series of phases or stanzas (Barlow 1961), with marked changes in the body shape, mostly in the early life cycle (Fonteles-Filho 2011). Thus, the growth analysis of juvenile versus adult fish should be conducted under separate LWRs to account for growth stanzas, ontogenetic changes, and developmental phases (Bervian et al. 2006, Froese 2006). The objective of this work was to produce LWR estimates for fishes, mostly juveniles, commonly found in shallow waters of sandy beaches of Guanabara Bay, one of the most important estuaries of south-eastern Brazil. This article is a part of a larger effort to advance research questions on the temporal and spatial patterns of fish recruitment and juvenile habitat use in tropical regions.

\section{MATERIAL AND METHODS}

Fishes were sampled in shallow waters of three sandy beaches of the lower Guanabara Bay estuary (outer zone under the marine influence) $\left(22^{\circ} 24^{\prime}-22^{\circ} 57^{\prime} \mathrm{S}, 42^{\circ} 33^{\prime}-\right.$ $\left.43^{\circ} 19^{\prime} \mathrm{W}\right)$, on a monthly basis between January 2012 and December 2015, under special collecting permit (SISBIO \#15787-1). Fishes were caught with a beach 
seine (16 $\mathrm{m}$ long, $2.5 \mathrm{~m}$ high, and $7.5 \mathrm{~mm}$ mesh) at sites, totalling 144 samples. The sampling unit considered was the total number of fish caught in three replicate tows at each location. All collected specimens were placed in plastic bags, labelled, stored on ice, and transported to the laboratory where they were screened and identified to the lowest taxonomic level. All fishes were measured for total length $( \pm 1 \mathrm{~mm})$ and weighed with an electronic scale $( \pm 0.01 \mathrm{~g})$.

The equation used to calculate LWRs was

$$
W=a \times L^{b},
$$

where, $W$ is the total weight of fishes [g], $a$ is the coefficient related to body shape, $L$ is the total length [cm], and $b$ is an exponent related to changes in body shape. The model was adjusted using Statistica 7.0 software, and parameters $a$ and $b$ were estimated by the log-linear regression

$$
\log (W)=\log a+b \log (L)
$$

Extreme outlier values were excluded from the analyses. Additionally, 95\% confidence limits (CL) of both $a$ and $b$ were estimated. The model fit was measured by the Pearson $r$-squared $\left(r^{2}\right)$ coefficient. The values of total length and $b$ were compared with the values reported in the FishBase and the literature. Also, the size of first sexual maturity was compiled from the literature to determine species life stages (juvenile/subadult or adult). Monthly length-frequency data were grouped and analysed using the Bhattacharya's method subroutine in the FISAT II package (FAO-ICLARM Stock Assessment Tools) (Sparre and Venema 1998) for cohort identification and estimation of the mean length for each modal group. Voucher specimens were deposited in the ichthyologic collection of ECOPESCA Laboratory at the Fluminense Federal University.

\section{RESULTS}

A total of 14457 individuals representing 15 species and ten families were collected. The following species were examined: Albula vulpes (Linnaeus, 1758); Harengula clupeola (Cuvier, 1829); Brevoortia aurea (Spix et Agassiz, 1829); Anchoa lyolepis (Evermann et Marsh, 1900); Umbrina coroides Cuvier, 1830; Menticirrhus littoralis (Holbrook, 1847); Menticirrhus americanus (Linnaeus, 1758); Trachinotus carolinus (Linnaeus, 1766); Trachinotus falcatus (Linnaeus, 1758); Diplodus argenteus (Valenciennes, 1830); Polydactylus virginicus (Linnaeus, 1758); Mugil curema Valenciennes, 1836; Haemulon aurolineatum Cuvier, 1830; Haemulon steindachneri (Jordan et Gilbert, 1882); Sphoeroides testudineus (Linnaeus, 1758). For each species, an adequate number of samples including mainly juveniles/ sub-adults and some adult stages were examined. The sampling program (four cycles) within the study area using the same fishing gear and a standardized effort allowed grouping the datasets to generate relative growth estimates of species. The best-represented family was the
Sciaenidae with three species, while the most abundant were: Harengula clupeola, Diplodus argenteus, Umbrina coroides, and Trachinotus carolinus. The LWR parameters and related statistics are presented in Table 1. Mean total lengths varied from $1.0 \mathrm{~cm}$ (Umbrina coroides and Menticirrhus littoralis) to $21.5 \mathrm{~cm}$ (Albula vulpes). The $a$ coefficient ranged from 0.0031 to 0.0315 , and the Pearson $r$-squared coefficient from 0.97 to 0.99 . The $b$ values between 2.66 and 3.32 were within the expected range and consistent with the literature (Froese 2006). Lengthweight relations for Diplodus argenteus were unavailable in FishBase (Froese and Pauly 2016), and the parameters here obtained are the first records in the scientific literature.

\section{DISCUSSION}

The great peculiarity of this study is a large number of small individuals of seven species, within minimum size ranges recorded in the literature. Individuals at TLs greater than the $L_{50}$ reported in the literature were obtained for Harengula clupeola and Sphoeroides testudineus and considered as adults. These findings suggest that populations from these two species included all strata (young-of-the-year, juvenile, and adult) in the studied sites, with individuals exploring the surf-zone/ shallow-water resources until completing sexual maturity. These findings further support the idea proposed by Froese (2006) in which separate LWRs should be used to account for growth stanzas, ontogenetic changes, and developmental phases.

Shallow marine habitats and the surf zone of sandy beaches have long been considered as nurseries for several fish species, many of commercial interest (MonteiroNeto and Musick 2003, Pereira et al. 2015). The high food availability (Amaral et al. 2016) and protection from larger fish predators (Félix et al. 2007) during the growing phase represent important assets for young fish. Thus, shallow marine habitats play the connectivity role between the young and the adult population (Beck et al. 2001) of species that are commonly found in other habitats as adults. For instance, Haemulon aurolineatum was collected at TLs between 2.74 and $4.46 \mathrm{~cm}$ in the presently reported study (Table 1). Adults of the species undergo changes in colour pattern and body form at 5.4 cm TL (Darcy 1983), and are often found near reefs (Monteiro-Neto et al. 2008). The absence of adults in our sampling suggests the part-time residency of the species in shallow waters during the juvenile phase.

Differences observed in $a$ and $b$ values of LWRs of fishes (same species or not) in the same habitat may be attributed to a combination of one or more factors:

- Number of specimens examined

- Fish habitat

- Health

- Sex

- Gonadal maturity

- Differences in the observed length ranges of the specimens and

- The preservation techniques used (Hossain et al. 2014) 


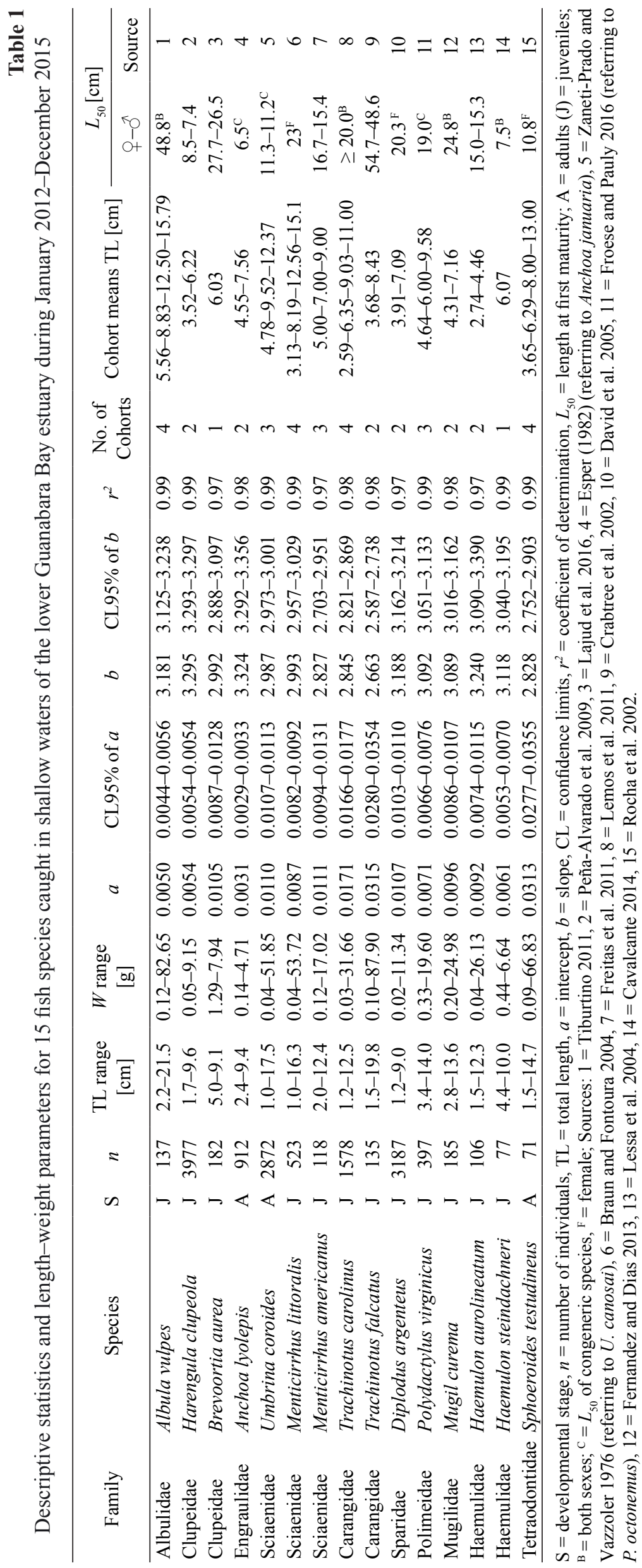


Froese (2006) and Gubiani et al. (2009) pointed out that variations in the exponent $b$ may be also attributed to different length ranges of the specimens and the areaseasonal effect. The presence of at least one mode, defined from a modal decomposition routine, is a good indication of habitat use by the species. The occurrence of multiple modes supports the premise of multiphase growth, common to most bony fishes (Bervian et al. 2006). Peyton et al. (2016) reinforced the idea that WLR estimates of juvenile fishes occurring in shallow waters are needed to compare temporal and spatial recruitment patterns. Petrakis and Stergiou (1995) observed that LWR parameters vary over a seasonal cycle within a year, depending on the average condition of the specimens. Fish habitat, sexual maturity, and size structure were addressed in the presently reported study, providing additional information towards the understanding of shallow habitats as nursery areas for several fish species in the tropical Atlantic, within the outer limits of an important estuarine environment, Guanabara Bay. Thus, the results of this study provide valuable information that will be helpful in future fisheries management and fish conservation.

\section{ACKNOWLEDGEMENTS}

Financial support was provided through a postdoctoral fellowship (PNPD) from the Coordenação de Aperfeiçoamento de Pessoal do Ensino Superior CAPES to R.A. Tubino, and a Research Productivity fellowship to C. Monteiro-Neto from the Conselho Nacional de Desenvolvimento Científico e Tecnológico - CNPq. We thank D.A. Borges for providing technical support. Undergraduate and graduate students at the Laboratório ECOPESCA, Departamento de Biologia Marinha, Instituto de Biologia, Universidade Federal Fluminense, helped in the fieldwork.

\section{REFERENCES}

Amaral A.C.Z., Corte G.N., Filho J.S.R., Denadai M.R., Colling L.A., Borzone C., Veloso V., Omena P., Zalmon I.R., Rocha-Barreira C.A., Souza J.R.B., Rosa L.C., Almeida T.C. 2016. Brazilian sandy beaches: Characteristics, ecosystem services, impacts, knowledge and priorities. Brazilian Journal of Oceanography 64 (2): 5-15. DOI: 10.1590/S1679875920160933064sp2

Barlow G.W. 1961. Causes and significance of morphological variation in fishes. Systematic Zoology 10 (3): 105-117. DOI: $10.2307 / 2411595$

Beck M.W., Heck K.L.jr., Able K.W., Childers D.L., Eggleston D.B., Gillanders B.M., Halpern B., Hays C.G., Hoshino K., Minello T.J., Orth R.J., Sheridan P.F., Weinstein M.P. 2001. The identification, conservation, and management of estuarine and marine nurseries for fish and invertebrates. BioScience 51 (8): 633-641. DOI: 10.1641/0006-3568(2001)051[0633:TICAMO]2.0.CO;2

Bervian G., Fontoura N.F., Haimovici M. 2006. Statistical model of variable allometric growth: Otolith growth in Micropogonias furnieri (Actinopterygii,
Sciaenidae). Journal of Fish Biology 68 (1): 196-208. DOI: $10.1111 / j .0022-1112.2006 .00890 . x$

Beyer J.E. 1987. On length-weight relationships. Part I: Computing the mean weight of the fish of a given length class. Fishbyte (Manila) 5 (1): 11-13.

Braun A.S., Fontoura N.F. 2004. Reproductive biology of Menticirrhus littoralis in southern Brazil (Actinopterygii: Perciformes: Sciaenidae). Neotropical Ichthyology 2 (1): 31-36. DOI: 10.1590/S167962252004000100005

Cavalcante C.C. 2014. O uso de habitats costeiros como berçário de peixes no Ceará [The use of coastal habitats as a fish nursery in Ceará.] (Doctoral dissertation). Universidade Federal do Ceará, Instituto de Ciências do Mar, Programa de Pós-Graduação em Ciências Marinhas Tropicais, Fortaleza. [In Potuguese.] http:// www.repositorio.ufc.br/handle/riufc/14931

Crabtree R.E., Hood P.B., Snodgrass D. 2002. Age, growth, and reproduction of permit (Trachinotus falcatus) in Florida waters. Fishery Bulletin 100 (1): 26-34.

da Costa M.R., Pereira H.H., Neves L.M., Araújo F.G. 2014. Length-weight relationships of 23 fish species from southeastern Brazil. Journal of Applied Ichthyology 30 (1): 230-232. DOI: 10.1111/jai.12275

Darcy G.H. 1983. Synopsis of biological data on the grunts Haemulon aurolineatum and $H$. plumieri (Pisces: Haemulidae). NOAA Technical Report NMFS Circular 448, FAO Fisheries Synopsis No. 133.

David G.S., Coutinho R., Quagio-Grassiotto I., Verani J.R. 2005. The reproductive biology of Diplodus argenteus (Sparidae) in the coastal upwelling system of Cabo Frio, Rio de Janeiro, Brazil. African Journal of Marine Science 27 (2): 439-447. DOI: $10.2989 / 18142320509504102$

Esper M.L.P. 1982. Reprodução e crescimento de Anchoa januaria (Steindachner, 1879) na região de Ponta da Cruz (Baía de Paranaguá), Paraná, Brasil. [Reproduction and growth of Anchoa januaria (Steindachner, 1879) in the region of Ponta da Cruz (Paranaguá Bay), Paraná, Brazil.] Dusenia, Curitiba 13 (1): 15-35. [In Portuguese.]

Félix F.C., Spach H.L., Moro P.S., Schwarz R.jr., Santos C., Hackradt C.W., Hostim-Silva M. 2007. Utilization patterns of surf zone inhabiting fish from beaches in southern Brazil. Pan-American Journal of Aquatic Sciences 2 (1): 27-39.

Fernandez W.S., Dias J.F. 2013. Aspects of the reproduction of Mugil curema Valenciennes, 1836 in two coastal systems in southeastern Brazil. Tropical Zoology 26 (1): 15-32. DOI: 10.1080/03946975.2013.775052

Fonteles-Filho A.A. 2011. Oceanografia, biologia e dinâmica populacional de recursos pesqueiros. [Oceanography, biology and population dynamics of fishery resources.] Expressão Gráfica e Editora. Fortaleza, Brazil. [In Portuguease.]

Freitas M.O., Haluch C.F., Abilhoa V., Corrêa M.F.M., Hostim-Silva M. 2011. Estrutura populacional e 
biologia reprodutiva de Menticirrhus americanus (Linnaeus, 1758) (Teleostei, Sciaenidae) na baía de Ubatuba-Enseada, Santa Catarina, Brasil. [Population structure and reproductive biology of Menticirrhus americanus (Linnaeus, 1758) (Teleostei, Sciaenidae) in Ubatuba-Enseada Bay, Santa Catarina, Brazil.] Biotemas 24 (1): 47-59. [In Portuguese.] DOI: 10.5007/2175-7925.2011v24n1p47

Froese R. 2006. Cube law, condition factor and weightlength relationships: history, meta-analysis and recommendations. Journal of Applied Ichthyology 22 (4): 241-253. DOI: 10.1111/j.1439-0426.2006.00805.x

Froese R., Pauly D. (eds.) 2016. FishBase. [Version 10/2016]. www.fishbase.org

Gubiani E.A., Gomes L.C., Agostinho A.A. 2009. Length-length and length-weight relationships for 48 fish species from reservoirs of the Paraná State, Brazil. Lakes and Reservoirs: Research and Management 14 (4): 289-299. DOI: 10.1111/j.14401770.2009.00411.x

Hossain M.Y., Rahman M.M., Ahmed F., Ahmed Z.F., Ohtomi J. 2014. Length-weight and length-length relationships and form factor of three threatened fishes from the Ganges River (NW Bangladesh). Journal of Applied Ichthyology 30 (1): 221-224. DOI: 10.1111/ jai.12251

Huxley J.S. 1924. Constant differential growth-ratios and their significance. Nature 114 (2877): 896-897. DOI: 10.1038/114895a0

Huxley J.S. 1993. Problems of relative growth; with a new introduction by Frederick B. Churchill and an essay by Richard E. Strauss. The John Hopkins University Press. Baltimore, MD, USA.

Lajud N.A., Astarloa J.M.D.D., González-Castro M. 2016. Reproduction of Brevoortia aurea (Spix and Agassiz, 1829) (Actinopterygii: Clupeidae) in the Mar Chiquita Coastal Lagoon, Buenos Aires, Argentina. Neotropical Ichthyology 14 (1): e150064. DOI: 10.1590/1982-0224-20150064

Le Cren E.D. 1951. The length-weight relationship and seasonal cycle in gonad weight and condition in the perch (Perca fluviatilis). Journal of Animal Ecology 20 (2): 201-219. DOI: $10.2307 / 1540$

Lemos V.M., Varela Junior A.S., Velasco G., Vieira J.P. 2011. The reproductive biology of the plata pompano, Trachinotus marginatus (Teleostei: Carangidae), in southern Brazil. Zoologia (Curitiba) 28 (5): 603-609. DOI: $10.1590 / \mathrm{S} 1984-46702011000500008$

Lessa R.P., Nóbrega M.F., Bezerra J.L.jr. (Orgs.) 2004. Dinâmica de populações e avaliação de estoques dos recursos pesqueiros da região nordeste. Volume II. Programa de avaliação do potencial sustentável dos recursos vivos da Zona Econômica Exclusiva, Score-NE. [Population dynamics and evaluation of stocks of fishery resources in the northeast region. Volume II. Program of evaluation of the sustainable potential of the living resources of the Exclusive Economic Zone, Score-NE.] DIMAR, Departamento de Pesca-Universidade Federal Rural de Pernambuco, Recife, Brazil. [In Portuguese.]
Lin Y.-J., Tzeng W.-N. 2010. Vital population statistics based on length frequency analysis of the exploited Japanese eel (Anguilla japonica) stock in the KaoPing River, southern Taiwan. Journal of Applied Ichthyology 26 (3): 424-431. DOI: 10.1111/j.14390426.2010.01453.x

Monteiro-Neto C., Cunha, L.P.R., Musick J.A. 2003. Community structure of surf-zone fishes at Cassino Beach, Rio Grande do Sul, Brazil. Journal of Coastal Research 35 (Special issue): 492-501.

Monteiro-Neto C., Tubino R.A., Moraes L.E.S., Mendonça Neto J.P., Esteves G.V., Fortes W.L. 2008. Associações de peixes na região costeira de Itaipu, Niterói, RJ. [Associations of fishes in the coastal region of Itaipu, Niterói, RJ.] Iheringia, Série Zoologia 98 (1): 50-59. DOI: 10.1590/S007347212008000100007

Peña-Alvarado N., Figuerola-Fernández M., TorresRuiz W. 2009. Reproductive biology of three important baitfishes (Clupeidae) in Puerto Rico. Pp. 38-47. In: Proceedings of the 61 st Gulf and Caribbean Fisheries Institute, 10-14 November 2008, Gosier, Guadeloupe, French West Indies.

Pereira H.H., Neves L.M., da Costa M.R., Araújo F.G. 2015. Fish assemblage structure on sandy beaches with different anthropogenic influences and proximity of spawning grounds. Marine Ecology 36 (1): 16-27. DOI: $10.1111 /$ maec. 12113

Petrakis G., Stergiou K.I. 1995. Weight-length relationships for 33 fish species in Greek waters. Fisheries Research 21 (3-4): 465-469. DOI: 10.1016/0165-7836(94)00294-7

Peyton K.A., Sakihara T.S., Nishiura L.K., Shindo T.T., Shimoda T.E., Hau S., Akiona A., Lorance K. 2016. Length-weight relationships for common juvenile fishes and prey species in Hawaiian estuaries. Journal of Applied Ichthyology 32 (3): 499-502. DOI: 10.1111/jai.12957

Rocha C., Favaro L.F., Spach H.L. 2002. Biologia reprodutiva de Sphoeroides testudineus (Linnaeus) (Pisces, Osteichthyes, Tetraodontidae) da gamboa do Baguaçu, Baía de Paranaguá, Paraná, Brasil. [Reproduetive biology of Sphoeroides testudineus (Linneus) (Pisces, Osteichthyes, Tetraodontidae) of the gamboa do Baguaçu, bay of Paranaguá, State of Paraná, Brazil.] Revista Brasileira de Zoologia 19 (1): 57-63. [In Portuguese.] DOI: 10.1590/S010181752002000100003

Romdhani A., Ktari M.H., Mahe K. 2013. Lengthweight relationship and condition factor of Phycis phycis (Linnaeus, 1766) and Phycis blennoides (Brünnich, 1768) [Actinopterygii, Gadiform, Phycidae] in the Gulf of Tunis. Bulletin de l'Institut National des Sciences et Technologies de la Mer de Salammbô 40: 3-13. DOI: 10.13140/RG.2.1.4128.3045

Sparre P., Venema S.C. 1998. Introduction to tropical fish stock assessment-Part 1: Manual. FAO Fisheries Technical Paper No. 306.1, Rev. 2. FAO, Rome. 
Tiburtino C. 2011. Atividade reprodutiva da ictiofauna acompanhante explotadas pela pesca de emalhe no litoral central de Alagoas. [Reproductive activity of the ichthyofauna by catch exploited by gill fishing in the central coast of Alagoas.] Masters dissertation. Universidade Federal de Alagoas. [In Potuguese.] http://www.repositorio.ufal.br/handle/riufal/960
Zaneti-Prado E.M., Vazzoler A.E.A.M. 1976. Alguns aspectos do ciclo de vida de Umbrina canosai na região da plataforma continental brasileira entre Cabo Frio $\left(23^{\circ} \mathrm{S}\right)$ e Torres $\left(29^{\circ} 21^{\prime} \mathrm{S}\right)$. [Some aspects of the life cycle of Umbrina canosai in the region of the Brazilian continental shelf between Cabo Frio $\left(23^{\circ} \mathrm{S}\right)$ and Torres $\left.\left(29^{\circ} 21^{\prime} \mathrm{S}\right)\right]$ P. 244. In: Resumos da $28^{\mathrm{a}}$ Reunião Anual da SBPC. [In Portuguese.]

Received: 25 April 2017

Accepted: 7 March 2018

Published electronically: 30 June 2018 